\title{
Nephrotoxicity in patients with solid tumors treated with anti-PD-1/PD-L1 monoclonal antibodies: a systematic review and meta-analysis
}

\author{
Han $\mathrm{Li}^{1}$ • Jinsheng Xu ${ }^{1} \cdot$ Yaling Bai ${ }^{1} \cdot$ Shenglei Zhang ${ }^{1} \cdot$ Meijuan Cheng ${ }^{1} \cdot$ Jingjing Jin ${ }^{1}$ \\ Received: 10 September 2020 / Accepted: 25 November 2020 / Published online: 6 January 2021 \\ (C) The Author(s) 2021
}

\section{Summary}

Background Programmed death-1 (PD-1) and programmed death ligand 1 (PD-L1) have dramatically improved cancer therapy for many patients. Adverse kidney effects have been found to be an important complication but have unclear mechanisms. Methods We searched Embase, PubMed, and the Cochrane Library to identify potential eligible studies. All included studies were randomized controlled trials (RCTs) examining patients with solid tumors treated with anti-PD-1/PD-L1 monoclonal antibodies (mAbs) and/or chemotherapy. The relative risk (RR) was used to assess the risk of nephrotoxic events. Results We included 27 clinical trials (15,063 patients). Compared with chemotherapy, the RR of all-grade nephritis was significantly increased with anti-PD-1/PD-L1 mAbs $(\mathrm{RR}=2.77,95 \%$ CI: 1.09-6.99, $P=0.03)$. Furthermore, anti-PD-1/PD-L1 mAbs plus chemotherapy can significantly increase the $\mathrm{RR}$ of all-grade nephritis $(\mathrm{RR}=2.99,95 \% \mathrm{CI}: 1.07-8.35, P=0.04)$. There was also a significant increase in the RRs of all-grade increased blood creatinine ( $\mathrm{RR}=1.88,95 \% \mathrm{CI}: 1.24-2.86, P=0.003)$ and acute kidney injury (AKI) $(\mathrm{RR}=3.35,95 \% \mathrm{CI}: 1.48-7.60, P=0.004)$. Conclusions Anti-PD-1/PD-L1 mAbs can significantly increase nephrotoxicity in patients with solid tumors, especially when combined with chemotherapy. During the application of these drugs, we should remain aware of nephrotoxicity for better efficacy. Trial registration number and date of registration Not applicable.

Keywords Anti-PD-1/PD-L1 monoclonal antibodies $\cdot$ Chemotherapy $\cdot$ Meta-analysis $\cdot$ Solid tumors $\cdot$ Nephrotoxicity

\section{Introduction}

According to estimates from the World Health Organization in 2015, cancer is the first or second leading cause of death before the age of 70 years in 91 of 172 countries, and it ranks third or fourth in an additional 22 countries [1]. Immune checkpoint inhibitors (ICIs) are the most recent breakthroughs in the treatment of cancer, and these agents have dramatically increased the therapeutic options for multiple cancers. Since December 2015, the Food and Drug Administration has approved two anti-PD-1 mAbs (nivolumab and pembrolizumab)

Jinsheng Xu

xjs5766@126.com

1 Department of Nephrology, Hebei Key Laboratory of Vascular Calcification in Kidney Disease, Hebei Clinical Research Center for Chronic Kidney Disease, The Fourth Hospital of Hebei Medical University, 12 Jiankang Road, Shijiazhuang 050011, People's Republic of China and three anti-PD-L1 mAbs (atezolizumab, durvalumab and avelumab). They function by increasing the activity of the immune system to inhibit the inactivation of $\mathrm{T}$ lymphocytes and thereby enhance anticancer and cytotoxic effects [2]. Compared with previous standards of care, cancer immunotherapy has led to significant improvements for patients in terms of survival and quality of life [3].

However, immune system activation is detrimental not only to the survival of cancer cells but also to certain types of healthy tissues [4]. Thus, a new group of adverse events, called immune-related adverse events (irAEs), has been recognized. Renal irAEs are rare, with an estimated incidence of $2 \%$ with anti-PD-1/PD-L1 mAbs and 5\% with combination therapy in a review of published phase 2 and 3 trials, but more recent studies have suggested that the incidence of AKI is higher than that initially reported $[5,6]$. Acute interstitial nephritis (AIN) is the most commonly reported pathology, and other forms of nephrotoxicity mostly manifest as increased blood creatinine and AKI [7]. One recent meta-analysis [8] 
examined the risk of nephrotoxicity associated with anti-PD1/PD-L1 mAbs using control groups that received placebo, chemotherapy or other immunotherapy but did not include the latest research. In contrast, our meta-analysis focused on nephrotoxicity in patients who received anti-PD-1/PD-L1 $\mathrm{mAbs}$ alone or in combination with chemotherapy. The combination therapy of anti-PD-1/PD-L1 agents and chemotherapy has become increasingly prevalent, but the effect of this more aggressive treatment on the risk and severity of nephrotoxicity relative to chemotherapy alone remains unknown.

To investigate the relationship between the incidence risk of immune-related nephrotoxic events and anti-PD-1/PD-L1 $\mathrm{mAbs}$, we performed this meta-analysis. Our systematic review and meta-analysis investigated the RR of nephrotoxicity in patients with solid tumors treated with anti-PD-1/PD-L1 mAbs alone, anti-PD-1/PD-L1 mAbs plus chemotherapy, or standard chemotherapy alone.

\section{Methods}

We searched Embase, PubMed, and the Cochrane Library to identify eligible studies. All included studies were RCTs that examined patients with solid tumors who received anti-PD-1/ PD-L1 mAbs and/or chemotherapy. Combined RRs and 95\% confidence intervals (CIs) and fixed- or random-effects methods were used to evaluate the nephrotoxicity caused by anti-PD-1/PD-L1 mAbs during treatment. This systematic review and meta-analysis was conducted according to the guidelines of the Cochrane Handbook for Systematic Reviews of Interventions [9], and the results were reported according to the PRISMA statement [10].

\section{Search strategy}

The PubMed, Cochrane and Embase databases were searched for RCTs using the following key words: "PD-1", "PD-L1", "nivolumab", "pembrolizumab", "atezolizumab", "durvalumab", and "avelumab" for publications on or before June 25, 2020.

\section{Inclusion and exclusion criteria}

According to our analysis design, the inclusion criteria were as follows: (1) studies on humans with solid tumors; (2) prospective RCTs; (3) studies that compared a PD-1/PD-L1 inhibitor with chemotherapy or a PD-1/PD-L1 inhibitor plus chemotherapy with the same chemotherapy agent (with or without placebo); and (4) studies that directly compared the nephrotoxicity data of patients receiving and not receiving anti-PD-1/ PD-L1 mAbs treatment (nephritis, increased blood creatinine and AKI).
Studies were excluded if they were phase I trials, singlearm studies, or trials where patients had no adverse renal events in either treatment arm; if patients received other agents simultaneously, such as targeted drugs; if they were retrospective studies, meeting abstracts, case reports, unfinished studies, duplicate reports, letters, or reviews; and if they were in any language other than English.

\section{Data extraction}

Two authors (J.J. and H.L.) independently evaluated all studies for eligibility by initially checking the titles, abstracts, and full texts of the studies following the patient, intervention, comparison, and outcome (PICO) chart [11]. The following information was extracted from all eligible studies: first author's name, year of publication, trial phase, treatment groups, primary endpoint, underlying solid malignancy, number of patients in each group, chemotherapy agents, and adverse events (AEs). The two categories of AEs were all-grade (1 to 5) and high-grade (3 to 5) renal AEs, namely, increased blood creatinine, AKI, and nephritis.

\section{Data analysis}

The risk of bias was assessed using Review Manager 5.3 software. Two authors independently assessed the quality of the included RCTs using the Cochrane risk of bias tool [12]. The relative risk (RR) was used to assess the risk of nephrotoxic events. We used Stata (version 12.0) to evaluate publication bias.

Heterogeneity among the RCTs was quantified using the Q test and $\mathrm{I}^{2}$ statistics. If the $\mathrm{I}^{2}$ value was less than $50 \%$, a fixedeffects model was used $[13,14]$; otherwise, a random-effects model was used. Sensitivity analysis was performed by removing one study at a time and recalculating the results. All $P$ values were 2 -tailed, and a $P$ value below 0.05 was considered significant.

\section{Results}

\section{Literature search}

Our initial search yielded 5861 potentially relevant clinical trials. After the removal of overlapping studies from the three databases and a review of the titles and abstracts, we initially excluded 5827 studies because they did not fulfill our criteria. The excluded studies included review articles, retrospective studies, case reports, phase I trials, single-arm studies, nonrandomized clinical trials, and studies of non-solid tumors. After a review of the full texts of the remaining 34 studies, we excluded 7 trials because they had no information related to nephrotoxicity (Fig. 1). The 27 eligible studies examined 
Fig. 1 Flowchart depicting the RCT selection process

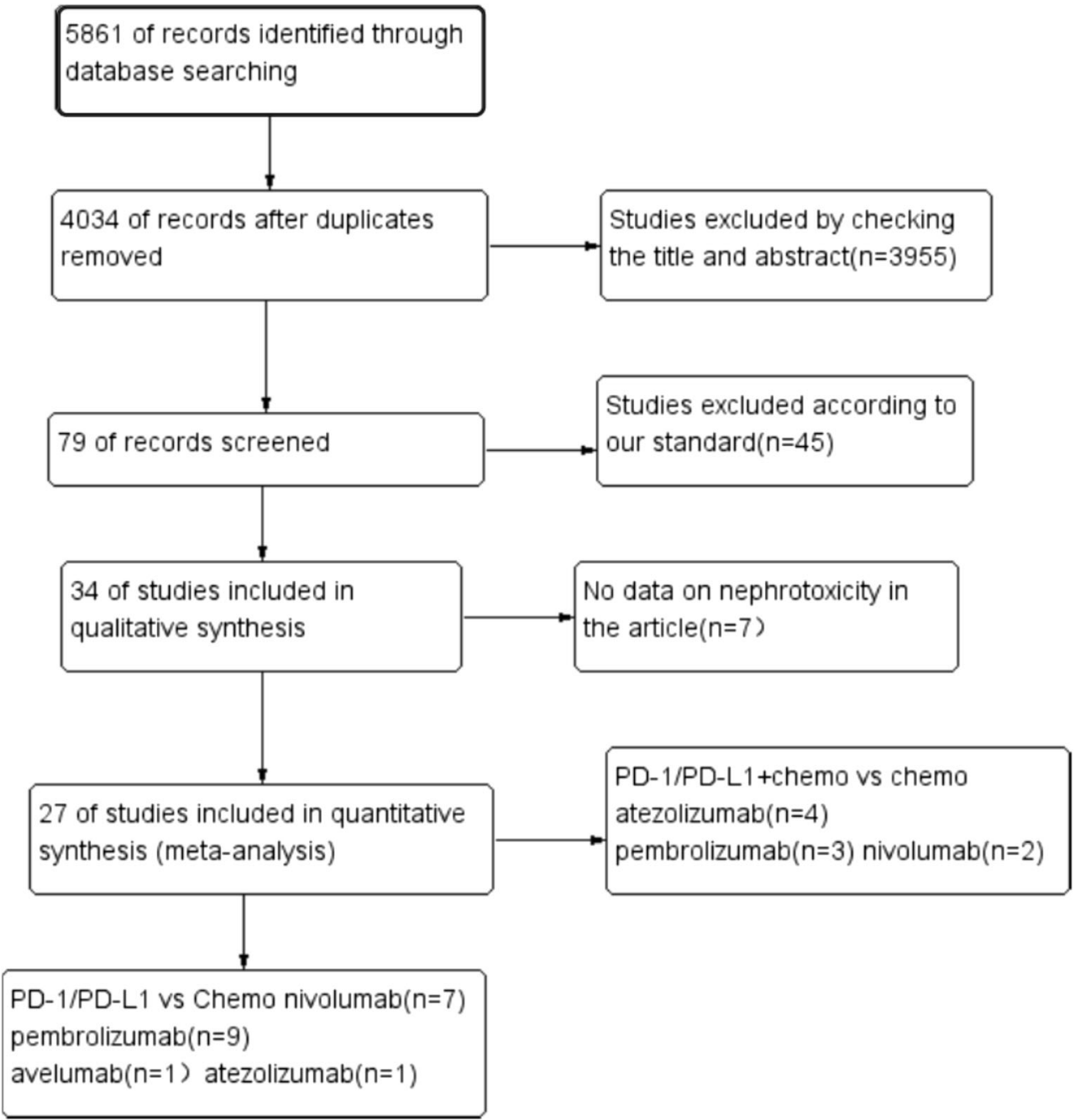

patients with non-small cell lung cancer (NSCLC, $n=13$ ), melanoma $(n=8)$, carcinoma of the head and neck $(n=2)$, renal cell carcinoma, small cell lung cancer, urothelial carcinoma, and breast cancer (1 each). None of the included RCTs examined durvalumab. The 27 studies in this meta-analysis examined 15,063 patients. Depending on the tumor type, the standard treatment the patient receives may be chemotherapy or ipilimumab, and four articles included RCTs of combination therapy or comparisons with ipilimumab.

Eighteen of the 27 studies examined anti-PD-1/PD-L1 mAbs vs. chemotherapy alone, and the other 9 studies examined anti-PD-1/PD-L1 mAbs plus chemotherapy vs. chemotherapy alone. The 18 studies of anti-PD-1/PD-L1 mAbs vs. chemotherapy examined patients treated with nivolumab (7 studies, 2536 patients), pembrolizumab (9 studies, 6452 patients), atezolizumab (1 study, 101 patients), and avelumab (1 study, 758 patients) (Reference: [15-32]). The 9 studies of anti-PD-1/PD-L1 mAbs plus chemotherapy vs. chemotherapy examined patients treated with atezolizumab (4 studies, 2776 patients), pembrolizumab (3 studies, 1286 patients), and nivolumab (2 studies, 1154 patients) (Reference: [33-41]). The literature was distributed from 2014 to 2019.

Tables 1 and 2 show the baseline details and the relevant all-grade and high-grade renal AEs in each trial. In this analysis, we graded all laboratory values according to the National Cancer Institute Common Terminology Criteria for Adverse Events version 4.0.

\section{Nephrotoxicity: Anti-PD-1/PD-L1 mAbs vs. chemotherapy}

\section{All- and high-grade increased blood creatinine and AKI}

The anti-PD-1/PD-L1 mAbs and chemotherapy groups had no significant differences in RR for all-grade increased blood creatinine and AKI and no significant differences for highgrade increased blood creatinine and AKI (Fig. S1 and Table S1). 
Table 1 Characteristics of the 18 randomized controlled trials that compared anti-PD-1/PD-L1 monoclonal antibodies vs. chemotherapy

\begin{tabular}{|c|c|c|c|c|c|c|c|c|c|c|}
\hline \multirow[t]{2}{*}{ Year } & \multirow[t]{2}{*}{ Trial phase } & \multirow[t]{2}{*}{ Tumor type } & \multirow[t]{2}{*}{ Treat arms } & \multirow[t]{2}{*}{ pts } & \multicolumn{2}{|c|}{ Nephritis } & \multicolumn{2}{|c|}{ Blood creatinine } & \multicolumn{2}{|l|}{ AKI } \\
\hline & & & & & G1-5 & G3-5 & G1-5 & G3-5 & G1-5 & G3-5 \\
\hline \multirow[t]{2}{*}{2014} & 3 & Melanoma & Niv $3 \mathrm{mg} / \mathrm{kg}$ every 2 weeks & 206 & $\mathrm{~N}$ & $\mathrm{~N}$ & 1 & 0 & 1 & 1 \\
\hline & & & Dac $1 \mathrm{~g} / \mathrm{m}^{2}$ every 3 weeks & 205 & $\mathrm{~N}$ & $\mathrm{~N}$ & 1 & 0 & 0 & 0 \\
\hline \multirow[t]{3}{*}{2015} & 2 & Melanoma & Pem $2 \mathrm{mg} / \mathrm{kg}$ every 3 weeks & 178 & 1 & 0 & $\mathrm{~N}$ & $\mathrm{~N}$ & $\mathrm{~N}$ & $\mathrm{~N}$ \\
\hline & & & Pem 10 mg/kg every 3 weeks & 179 & 1 & 0 & $\mathrm{~N}$ & $\mathrm{~N}$ & $\mathrm{~N}$ & $\mathrm{~N}$ \\
\hline & & & ICC every 3 weeks & 171 & 0 & 0 & $\mathrm{~N}$ & $\mathrm{~N}$ & $\mathrm{~N}$ & $\mathrm{~N}$ \\
\hline \multirow[t]{2}{*}{2015} & 3 & Melanoma & Pem $10 \mathrm{mg} / \mathrm{kg}$ every $2 / 3$ weeks & 555 & 1 & 0 & $\mathrm{~N}$ & $\mathrm{~N}$ & $\mathrm{~N}$ & $\mathrm{~N}$ \\
\hline & & & Ipilimumab $3 \mathrm{mg} / \mathrm{kg}$ every 3 weeks & 256 & 1 & 1 & $\mathrm{~N}$ & $\mathrm{~N}$ & $\mathrm{~N}$ & $\mathrm{~N}$ \\
\hline \multirow[t]{2}{*}{2015} & 3 & NSCL & Niv $3 \mathrm{mg} / \mathrm{kg}$ every 2 weeks & 287 & $\mathrm{~N}$ & $\mathrm{~N}$ & 5 & 0 & 1 & 0 \\
\hline & & & Doc $75 \mathrm{mg} / \mathrm{m}^{2}$ every 3 weeks & 268 & $\mathrm{~N}$ & $\mathrm{~N}$ & 1 & 0 & 0 & 0 \\
\hline \multirow[t]{2}{*}{2015} & 3 & Melanoma & Niv $3 \mathrm{mg} / \mathrm{kg}$ every 2 weeks & 268 & $\mathrm{~N}$ & $\mathrm{~N}$ & 2 & 0 & $\mathrm{~N}$ & $\mathrm{~N}$ \\
\hline & & & ICC every 3 weeks & 102 & $\mathrm{~N}$ & $\mathrm{~N}$ & 0 & 0 & $\mathrm{~N}$ & $\mathrm{~N}$ \\
\hline \multirow[t]{2}{*}{2016} & 3 & NSCL & Pem 200 mg every 3 weeks & 154 & 1 & 1 & 3 & 0 & $\mathrm{~N}$ & $\mathrm{~N}$ \\
\hline & & & platinum-based chemotherapy & 150 & 0 & 0 & 15 & 1 & $\mathrm{~N}$ & $\mathrm{~N}$ \\
\hline \multirow[t]{2}{*}{2016} & 3 & Head-and-neck & Niv $3 \mathrm{mg} / \mathrm{kg}$ every 2 weeks & 236 & $\mathrm{~N}$ & $\mathrm{~N}$ & $\mathrm{~N}$ & $\mathrm{~N}$ & 1 & 0 \\
\hline & & & Methotrexate/Doc/cetuximab & 111 & $\mathrm{~N}$ & $\mathrm{~N}$ & $\mathrm{~N}$ & $\mathrm{~N}$ & 2 & 1 \\
\hline \multirow[t]{3}{*}{2016} & $2 / 3$ & NSCL & Pem 2 mg/kg every 3 weeks & 339 & $\mathrm{~N}$ & $\mathrm{~N}$ & 6 & 0 & $\mathrm{~N}$ & $\mathrm{~N}$ \\
\hline & & & Pem 10 mg/kg every 3 weeks & 343 & $\mathrm{~N}$ & $\mathrm{~N}$ & 7 & 0 & $\mathrm{~N}$ & $\mathrm{~N}$ \\
\hline & & & Doc $75 \mathrm{mg} / \mathrm{m}^{2}$ every 3 weeks & 309 & $\mathrm{~N}$ & $\mathrm{~N}$ & 0 & 0 & $\mathrm{~N}$ & $\mathrm{~N}$ \\
\hline \multirow[t]{2}{*}{2017} & 3 & Urothelial Carcinoma & Pem 200 mg every 3 weeks & 266 & 2 & 2 & 13 & 2 & 15 & 7 \\
\hline & & & ICC every 3 weeks & 255 & 0 & 0 & 15 & 1 & 7 & 3 \\
\hline \multirow[t]{2}{*}{2017} & 3 & NSCL & Niv 3 mg/kg every 2 weeks & 267 & $\mathrm{~N}$ & $\mathrm{~N}$ & 5 & 1 & $\mathrm{~N}$ & $\mathrm{~N}$ \\
\hline & & & Platinum-based ICC every 3 weeks & 263 & $\mathrm{~N}$ & $\mathrm{~N}$ & 16 & 0 & $\mathrm{~N}$ & $\mathrm{~N}$ \\
\hline \multirow[t]{2}{*}{2017} & 3 & SC-NSCL & Niv3mg/kg every 2 weeks & 131 & 1 & 1 & 4 & 0 & 0 & 0 \\
\hline & & & Docetaxe $175 \mathrm{mg} / \mathrm{m}^{2}$ every 3 weeks & 129 & 0 & 0 & 2 & 0 & 1 & 1 \\
\hline \multirow[t]{2}{*}{2017} & 3 & Melanoma & Pembrolizumab $10 \mathrm{mg} / \mathrm{kg}$ every 3 weeks & 277 & 2 & 2 & $\mathrm{~N}$ & $\mathrm{~N}$ & $\mathrm{~N}$ & $\mathrm{~N}$ \\
\hline & & & ipilimumab $3 \mathrm{mg} / \mathrm{kg}$ every 3 weeks & 278 & 0 & 0 & $\mathrm{~N}$ & $\mathrm{~N}$ & $\mathrm{~N}$ & $\mathrm{~N}$ \\
\hline \multirow[t]{2}{*}{2018} & 3 & Head-and-neck & Pem 200 mg every 3 weeks & 246 & $\mathrm{~N}$ & $\mathrm{~N}$ & 0 & 0 & 1 & 1 \\
\hline & & & Methotrexate/Doc & 234 & $\mathrm{~N}$ & $\mathrm{~N}$ & 2 & 0 & 1 & 0 \\
\hline \multirow[t]{2}{*}{2018} & 3 & NSCL & Avelumab $10 \mathrm{mg} / \mathrm{kg}$ every 2 weeks & 393 & $\mathrm{~N}$ & $\mathrm{~N}$ & $\mathrm{~N}$ & $\mathrm{~N}$ & 1 & 1 \\
\hline & & & Docetaxel $75 \mathrm{mg} / \mathrm{m}^{2}$ every 3 weeks & 365 & $\mathrm{~N}$ & $\mathrm{~N}$ & $\mathrm{~N}$ & $\mathrm{~N}$ & 0 & 0 \\
\hline \multirow[t]{2}{*}{2018} & 3 & Melanoma & Pembrolizumab $200 \mathrm{mg}$ every 3 wees & 509 & 2 & 2 & $\mathrm{~N}$ & $\mathrm{~N}$ & $\mathrm{~N}$ & $\mathrm{~N}$ \\
\hline & & & placebo every 3 weeks & 502 & 1 & 0 & $\mathrm{~N}$ & $\mathrm{~N}$ & $\mathrm{~N}$ & $\mathrm{~N}$ \\
\hline \multirow[t]{2}{*}{2018} & 3 & NSCL & Atezolizumab & 56 & 1 & 1 & $\mathrm{~N}$ & $\mathrm{~N}$ & $\mathrm{~N}$ & $\mathrm{~N}$ \\
\hline & & & Docetaxel & 45 & 0 & 0 & $\mathrm{~N}$ & $\mathrm{~N}$ & $\mathrm{~N}$ & $\mathrm{~N}$ \\
\hline 2019 & 3 & NSCL & Pem 200 mg every 3 weeks & 636 & 3 & 1 & $\mathrm{~N}$ & $\mathrm{~N}$ & $\mathrm{~N}$ & $\mathrm{~N}$ \\
\hline & & & Platinum-based ICC every 3 weeks & 615 & 0 & 0 & $\mathrm{~N}$ & $\mathrm{~N}$ & $\mathrm{~N}$ & $\mathrm{~N}$ \\
\hline 2019 & 3 & Renal cell carcinoma & Niv $3 \mathrm{mg} / \mathrm{kg}$ every 3 weeks & 37 & $\mathrm{~N}$ & $\mathrm{~N}$ & 1 & 0 & $\mathrm{~N}$ & $\mathrm{~N}$ \\
\hline & & & Everolimus 10 mg every day & 26 & $\mathrm{~N}$ & $\mathrm{~N}$ & 4 & 0 & $\mathrm{~N}$ & $\mathrm{~N}$ \\
\hline
\end{tabular}

Niv nivolumab, ICC investigator's choice of chemotherapy, $N$ not available, $N S C L C$ non-small cell lung cancer, Doc docetaxel, Dac dacarbazine, $P F S$ progression-free survival, Pem pembrolizumab, Pac Paclitaxel, UC urothelial cancer, Ave avelumab

\section{All- and high-grade nephritis}

When comparing anti-PD-1/PD-L1 mAbs vs. chemotherapy, there was a significant increase in the RR of all-grade nephritis (RR $=2.77,95 \%$ CI: $1.09-6.99, P=0.03$; Fig. 2 ).
Nephrotoxicity: anti-PD-1/PD-L1 mAbs plus chemotherapy vs. chemotherapy

All- and high-grade increased blood creatinine and AKI When comparing anti-PD-1/PD-L1 mAbs plus chemotherapy 
Table 2 Characteristics of the 9 randomized controlled trials that compared anti-PD-1/PD-L1 monoclonal antibodies plus chemotherapy vs. chemotherapy

\begin{tabular}{|c|c|c|c|c|c|c|c|c|c|c|}
\hline \multirow[t]{2}{*}{ Year } & \multirow[t]{2}{*}{$\begin{array}{l}\text { Trial } \\
\text { phase }\end{array}$} & \multirow[t]{2}{*}{ Tumor type } & \multirow[t]{2}{*}{ Treat arms } & \multirow[t]{2}{*}{ pts } & \multicolumn{2}{|c|}{ Nephritis } & \multicolumn{2}{|c|}{$\begin{array}{l}\text { Blood } \\
\text { creatinine }\end{array}$} & \multicolumn{2}{|l|}{ AKI } \\
\hline & & & & & $\begin{array}{l}\text { G1- } \\
5\end{array}$ & $\begin{array}{l}\text { G3- } \\
5\end{array}$ & $\begin{array}{l}\text { G1- } \\
5\end{array}$ & $\begin{array}{l}\text { G3- } \\
5\end{array}$ & $\begin{array}{l}\text { G1- } \\
5\end{array}$ & $\begin{array}{l}\text { G3 } \\
5\end{array}$ \\
\hline \multirow[t]{2}{*}{2016} & 3 & Advanced melanoma & Nivolumab $1 \mathrm{mg} / \mathrm{kg}$ + ipilimumab $3 \mathrm{mg} / \mathrm{kg}$ & 94 & $\mathrm{~N}$ & $\mathrm{~N}$ & 2 & 1 & $\mathrm{~N}$ & $\mathrm{~N}$ \\
\hline & & & Ipilimumab $3 \mathrm{mg} / \mathrm{kg}$ + placebo & 46 & $\mathrm{~N}$ & $\mathrm{~N}$ & 0 & 0 & $\mathrm{~N}$ & $\mathrm{~N}$ \\
\hline \multirow[t]{2}{*}{2017} & 3 & Advanced melanoma & Niv $1 \mathrm{mg} / \mathrm{kg}+$ ipilimumab $3 \mathrm{mg} / \mathrm{kg}$ every 3 weeks & 313 & $\mathrm{~N}$ & $\mathrm{~N}$ & 14 & 1 & $\mathrm{~N}$ & $\mathrm{~N}$ \\
\hline & & & Ipilimumab $3 \mathrm{mg} / \mathrm{kg}+$ placebo & 311 & $\mathrm{~N}$ & $\mathrm{~N}$ & 5 & 0 & $\mathrm{~N}$ & $\mathrm{~N}$ \\
\hline \multirow[t]{2}{*}{2018} & 3 & $\begin{array}{l}\text { Non-squamous } \\
\text { NSCLC }\end{array}$ & Pem 200 mg + Platinum-based ICC every 3 weeks & 405 & 7 & 6 & 36 & 2 & 21 & 8 \\
\hline & & & Placebo + Platinum-based ICC every 3 weeks & 202 & 0 & 0 & 11 & 0 & 1 & 1 \\
\hline \multirow[t]{2}{*}{2018} & 3 & ES-SCLC & Ate $1200 \mathrm{mg}+$ Chemo (Car + Eto) every 3 weeks & 198 & 1 & 1 & 1 & 0 & 4 & 2 \\
\hline & & & Placebo + Chemo $($ Car + Eto $)$ every 3 weeks & 196 & 1 & 0 & 0 & 0 & 1 & 0 \\
\hline \multirow[t]{2}{*}{2018} & 3 & $\begin{array}{l}\text { Squamous-cell } \\
\quad \text { NSCLC }\end{array}$ & Pem 200 mg + Chemo (Car+[Nb-]pac) every 3 weeks & 278 & 2 & 2 & $\mathrm{~N}$ & $\mathrm{~N}$ & 0 & 0 \\
\hline & & & Placebo + Chemo $(\mathrm{Car}+[\mathrm{Nb}-]$ pac $)$ every 3 weeks & 280 & 2 & 2 & $\mathrm{~N}$ & $\mathrm{~N}$ & 1 & 1 \\
\hline \multirow[t]{2}{*}{2018} & 3 & First-line NSCLC & Ate $1200 \mathrm{mg}+\mathrm{Bev}+\mathrm{Car}+$ Pac every 3 weeks & 393 & 3 & 1 & $\mathrm{~N}$ & $\mathrm{~N}$ & 2 & 1 \\
\hline & & & Bev $15 \mathrm{mg} / \mathrm{kg}+\mathrm{Car}+$ Pac every 3 weeks & 394 & 0 & 0 & $\mathrm{~N}$ & $\mathrm{~N}$ & 1 & 1 \\
\hline \multirow[t]{2}{*}{2018} & 3 & Triple-negative $\mathrm{BC}$ & Ate $840 \mathrm{mg}+\mathrm{Nb}$-pac100 mg/m2 d1,8,15 every4weeks & 452 & 1 & 0 & $\mathrm{~N}$ & $\mathrm{~N}$ & $\mathrm{~N}$ & $\mathrm{~N}$ \\
\hline & & & Placebo+ Nb-pac100 mg/m2 d 1,8,15 every4weeks & 438 & 0 & 0 & $\mathrm{~N}$ & $\mathrm{~N}$ & $\mathrm{~N}$ & $\mathrm{~N}$ \\
\hline \multirow[t]{2}{*}{2016} & 2 & $\begin{array}{l}\text { Non-squamous } \\
\text { NSCLC }\end{array}$ & $\begin{array}{l}\text { Pem } 200 \mathrm{mg}+\text { Chemo }(\mathrm{Car}+\text { pemetrexed }) \text { every } \\
3 \text { weeks }\end{array}$ & 59 & $\mathrm{~N}$ & $\mathrm{~N}$ & 6 & 0 & 2 & 2 \\
\hline & & & Chemo (Car + pemetrexed) every 3 weeks & 62 & $\mathrm{~N}$ & $\mathrm{~N}$ & 4 & 0 & 1 & 0 \\
\hline \multirow[t]{2}{*}{2019} & 3 & $\begin{array}{l}\text { Non-squamous } \\
\text { NSCLC }\end{array}$ & Ate $1200 \mathrm{mg}+$ CarAUC6 q3w + Nb-pac100mg/m2qw & 473 & 4 & 1 & 26 & 2 & 9 & 4 \\
\hline & & & CarAUC6q3w + Nb-pac100mg/m2qw & 232 & 0 & 0 & 7 & 0 & 3 & 1 \\
\hline
\end{tabular}

Chemo chemotherapy, Car carboplatin, ES-SCLC extensive-stage small-cell lung cancer, Niv nivolumab, Ate Atezolizumab, Eto etoposide, BC breast cancer, Bev bevacizumab, $A U C$ area under the curve

and chemotherapy, there was a significant increase in the $\mathrm{RR}$ of all-grade increased blood creatinine $(\mathrm{RR}=1.88$, 95\% CI: 1.24-2.86, $P=0.003$ ) and AKI (RR $=3.35$, 95\% CI: $1.48-7.60, P=0.004$; Fig. 3). The two groups had no significant differences in the RRs of high-grade increased blood creatinine and high-grade AKI (Fig. S2 and Table S2).

All- and high-grade nephritis When comparing anti-PD-1/PDL1 mAbs plus chemotherapy and chemotherapy, there was a

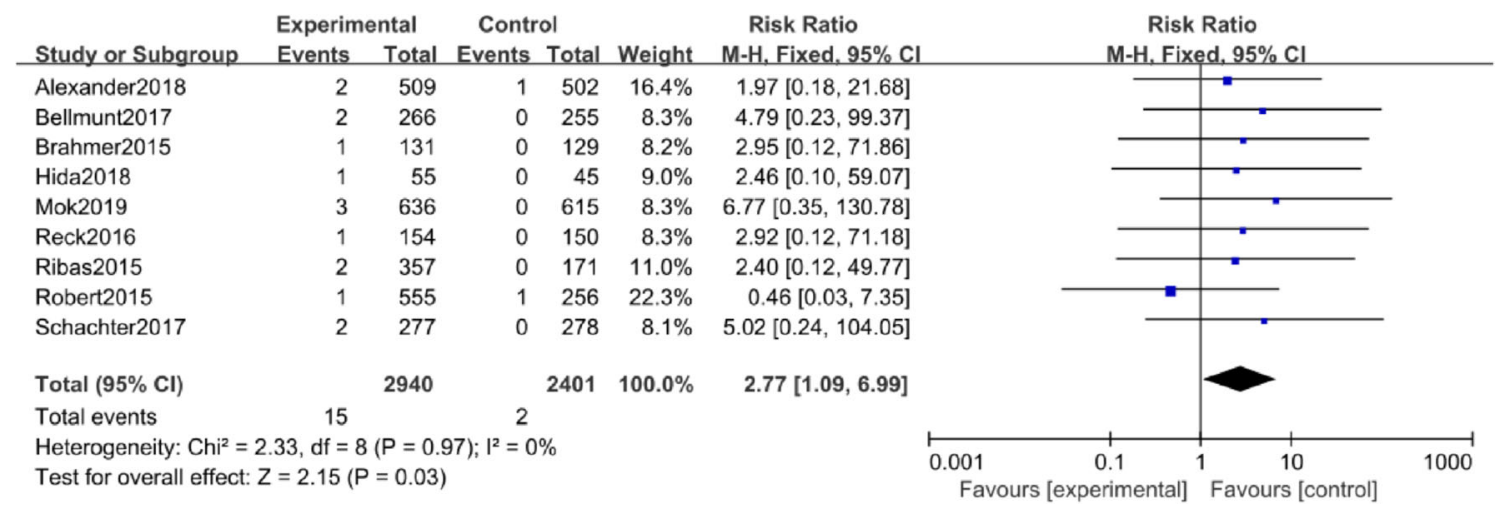

Fig. 2 Forest plot for all-grade nephritis in studies that compared anti-PD-1/PD-L1 mAbs and chemotherapy 


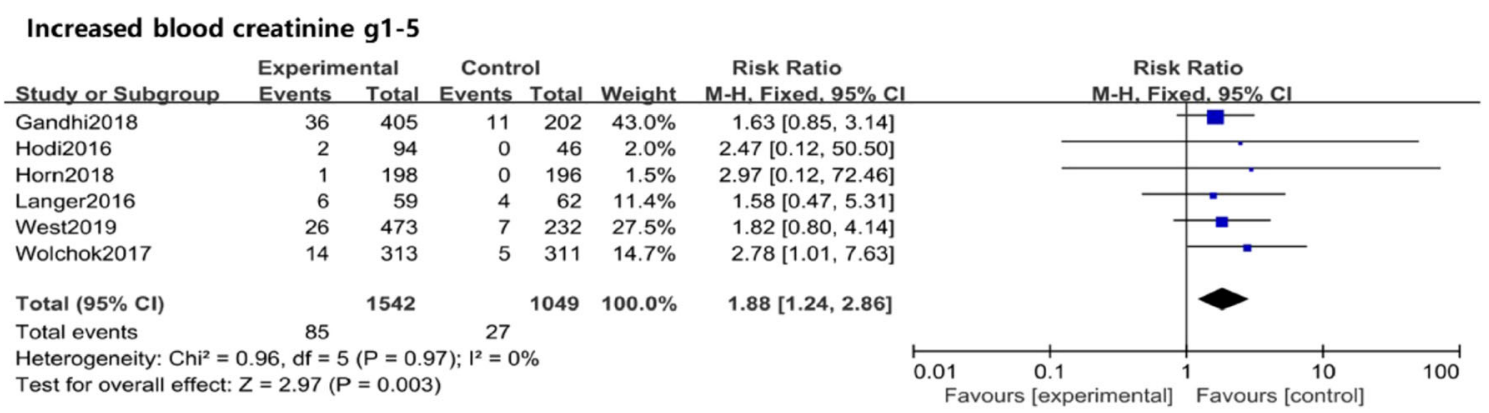

Acute kidney injury g1-5

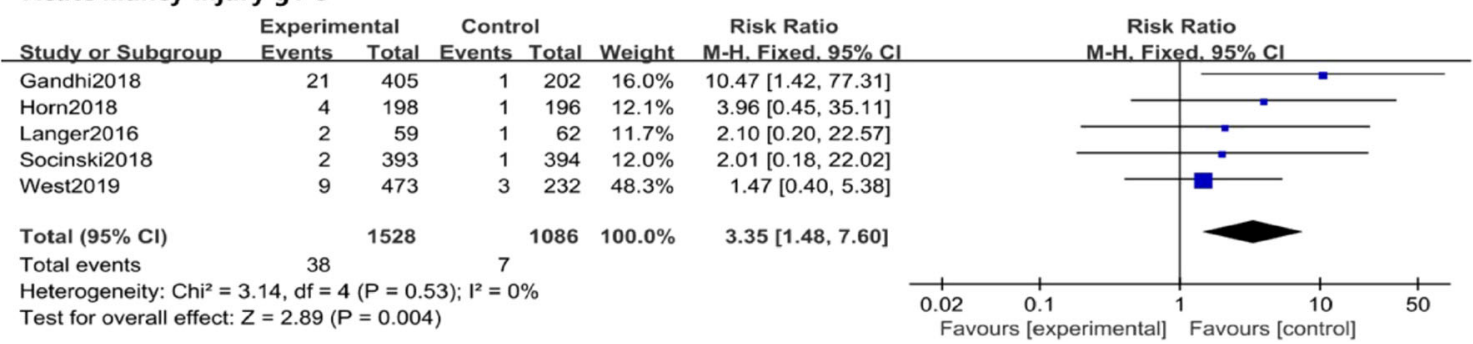

Fig. 3 Forest plot for all grade increased blood creatinine and acute kidney injury caused by anti-PD-1/PD-L1 mAbs plus chemotherapy

significant increase in the RR of all-grade nephritis (RR $=2.99,95 \%$ CI: $1.07-8.35, P=0.04$; Fig. 4).

\section{Quality assessment and publication bias}

All studies were randomized controlled trials. Analysis using the Cochrane risk of bias tool indicated a low risk of bias for all included studies (Fig. 5). We used a fixed effects model for most comparisons due to the low heterogeneity among the included studies. Only one comparison used a random effects model and sensitivity analysis, and the results were not affected. The results of Begg's test and Egger's test indicated no evidence of publication bias.

\section{Discussion}

The results of our analysis of 27 clinical trials including 15,063 cancer patients indicated that anti-PD-1/PD-L1 mAbs were associated with a higher risk of all-grade nephrotoxicity than control treatments. The 18 studies that examined antiPD-1/PD-L1 mAbs vs. chemotherapy alone were distributed from 2014 to 2019, and the 9 studies that examined anti-PD-1/ PD-L1 mAbs plus chemotherapy vs. chemotherapy alone were distributed from 2016 to 2019. Anti-PD-1/PD-L1 mAbs monotherapy was applied early, and the studies had a wider time distribution. Combination strategies with conventional and immunotherapies were approved later but have gradually become the focus of attention. Similar to the literature we retrieved, the related RCTs were mostly distributed in the last 4 years. Our findings bridged the gap in previous studies by comparing the risk of renal toxicity in cancer patients receiving anti-PD-1/PD-L1 mAbs with or without chemotherapy vs. chemotherapy alone.

In our results, there was a significant increase in the RR of allgrade nephritis in patients receiving anti-PD-1/PD-L1 mAbs alone. Previous studies have shown that acute tubulointerstitial nephritis (ATIN) is the most commonly reported pathological lesion in patients who have received anti-PD-1/PD-L1 mAbs therapy [42]. Based on a recent retrospective cohort analysis of more than 1000 people, the majority of potential immune

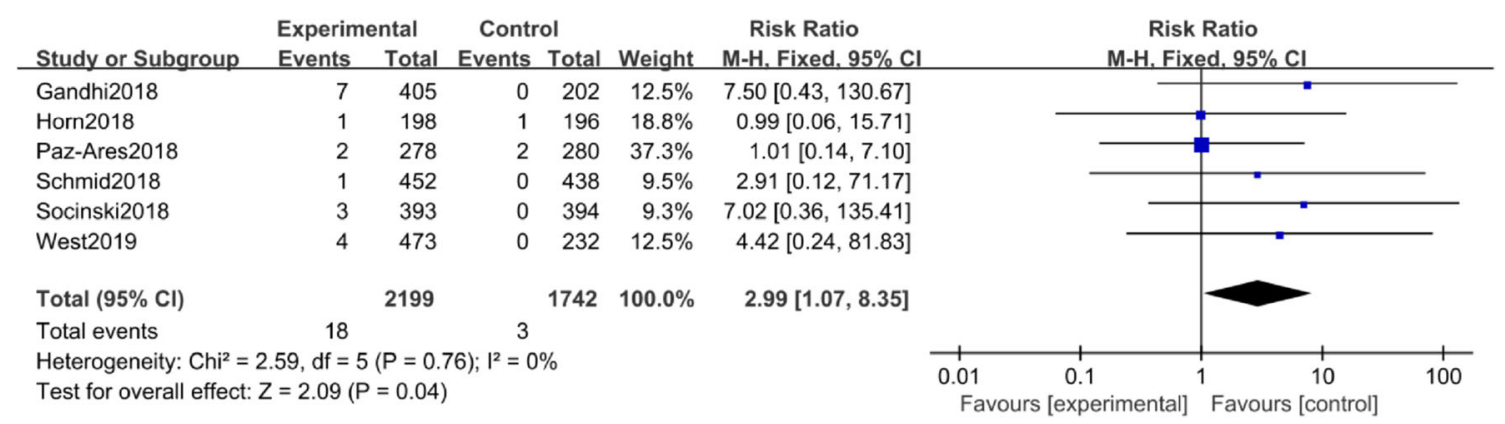

Fig. 4 Forest plot for all-grade nephritis in studies that compared anti-PD-1/PD-L1 mAbs plus chemotherapy and chemotherapy 


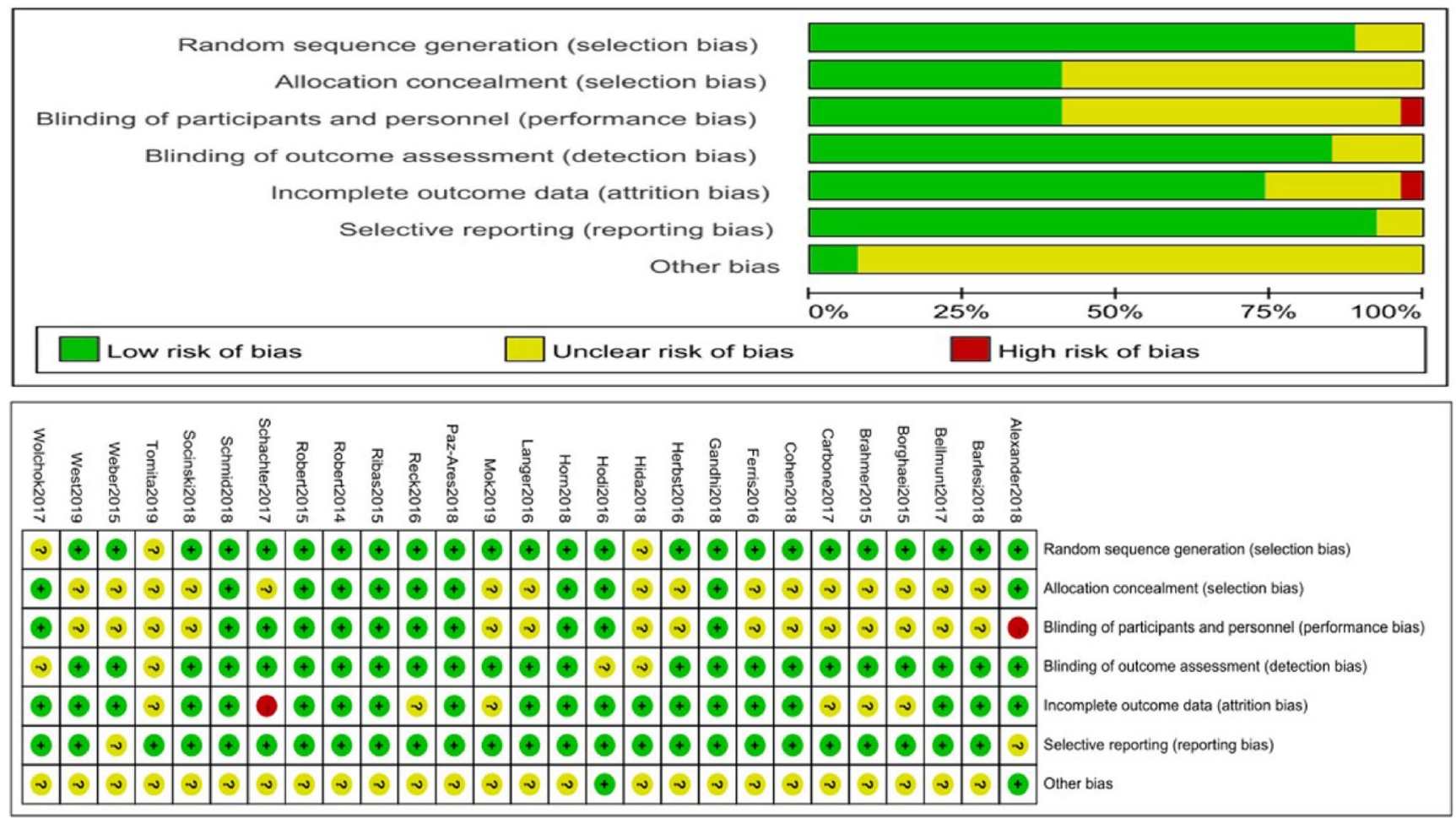

Fig. 5 Risk of bias summary. a Bar chart comparing the percentage of the risk of bias for each included RCT. Low risk of bias (green), high risk of bias (red), and unclear risk of bias (yellow). b Risk of bias for each

checkpoint inhibitor-related events were secondary to varying degrees of tubular and interstitial inflammation and injury [43]. These results are consistent with our results. From the perspective of nephrotoxicity, acute interstitial nephritis (AIN) is the most common biopsy-proven diagnosis in patients treated with checkpoint inhibitors who develop kidney injury. The mechanism of renal irAEs is still a research focus. According to theories supported by most researchers, $\mathrm{T}$ cells are more likely to lose tolerance to native kidney antigens in the presence of antiPD-1/PD-L1 mAbs, and uninhibited T cells may activate the typical drug-induced hypersensitivity reaction pathway more vigorously [44]. Thus, AIN is induced by anti-PD-1/PD-L1 mAbs, which may be due to the reprogramming of the immune system, leading to the loss of tolerance against endogenous kidney antigens [44]. The interpretation of pathological types is of great help in the treatment of immune-related nephrotoxicity. When treating patients with anti-PD-1/PD-L1 mAbs alone, physicians should be alert to the possible clinical manifestations of nephritis. If there are potential alternative reasons for AKI, a lower threshold to perform a renal biopsy should be used.

When comparing anti-PD-1/PD-L1 mAbs plus chemotherapy and chemotherapy, there was also a significant increase in the RRs of all-grade increased blood creatinine and AKI. Compared with monotherapy, anti-PD-1/PD-L1 mAbs plus chemotherapy led to increased nephrotoxicity, which can cause AKI. In a combined analysis of 3695 patients treated with ICIs, AKI was more common in patients receiving combination included RCT, representing low risk of bias (+), high risk of bias (-), and unclear risk of bias (?)

therapy than in patients receiving ICI monotherapy [5], which is consistent with our results. The combined literature revealed the following characteristics of ICI-related AKI. Most patients had AKI with tubulointerstitial presentation, including normal urinary output, granular casts, aseptic leukocyturia, and lowgrade ( $0.1 \mathrm{~g}$ per day) or no proteinuria [43]. A review of 13 cases from seven academic centers in the USA concluded that the great majority of cases of AKI with ICIs are due to AIN [5]. According to our analysis, AKI was likely to be secondary to varying degrees of tubular and interstitial inflammation and injury. However, it is important to note that there have been recent reports of glomerular diseases, including lupus nephritis, vasculitis, and podocytopathies [45]. In addition, chemotherapy drugs can also cause many types of kidney injury, such as AIN, thrombotic microangiopathy, and acute tubular necrosis, which may aggravate damage to the tubule and interstitium and lead to higher nephrotoxicity. Treatment should be suspended for complications above grade 2 , and a corticosteroid regimen should be used promptly for complications above grade 3 [46]. Therefore, when using anti-PD-1/PD-L1 mAbs plus chemotherapy, we should be more vigilant about nephrotoxicity and changes in blood creatinine. Continuous laboratory testing and necessary treatment are the basis of our treatment process.

This meta-analysis has some limitations. First, due to the lack of reports of renal adverse events in many studies, the number of qualified publications is limited. In addition, due to the heterogeneity of the selected RCTs and different 
diagnostic criteria, the identification of immune-related nephrotoxicity by researchers and organizations may not be completely consistent. Second, we were unable to obtain the patient's personal information or the patient's long-term follow-up data, so we did not consider the details of immunerelated nephrotoxicity. Similarly, although patients with advanced tumors sometimes develop kidney metastases, the lack of patient-level information limits our ability to identify specific abnormalities in patients with renal adverse events.

\section{Conclusion}

Anti-PD-1/PD-L1 mAbs can significantly increase nephrotoxicity in patients with solid tumors, especially when combined with chemotherapy. During the application of these drugs, we should remain aware of nephrotoxicity for better efficacy.

Supplementary Information The online version contains supplementary material available at https://doi.org/10.1007/s10637-020-01039-5.

Acknowledgements We thank J.J. for providing help for this article.

Data availability The datasets used or analysed during the current study are available from the corresponding author on reasonable request.

Author contributions All authors contributed to the study conception and design. The retrieval and screening of the literature was performed by Jingjing Jin and Han Li. The collection of relevant data and the first draft of the manuscript were carried out by Li Han. All authors commented on previous versions of the manuscript. Jingjing Jin and Meijuan Cheng revised the manuscript critically for important intellectual content. All authors read and approved the final manuscript.

Funding This work was supported by the Hebei Major Medical Science Project (GL2011-51), the Hebei Science and Technology Planning Project (16397733D), the Hebei Province Medical Technology Tracking Project (G2018050) and the Hebei Province Key Research and Development Project (20377704D).

\section{Compliance with ethical standards}

Disclosure of potential conflicts of interest None of the authors disclose any financial, consulting or personal relationships with other people or organizations that could influence the authors' work.

Research involving human participants and/or animals This article does not contain any studies with human participants or animals performed by any of the authors.

Informed consent Informed consent was obtained from all individual participants included in the study.

Ethical approval and consent to participate We did not use individual data but used published data. These data have been widely utilized in research and are generally available. Therefore, we confirm that any aspect of the work covered in this manuscript has been conducted with ethical approval.
Consent for publication Written informed consent for publication was obtained from all participants.

Competing interests The authors do not have any possible conflicts of interest.

Open Access This article is licensed under a Creative Commons Attribution 4.0 International License, which permits use, sharing, adaptation, distribution and reproduction in any medium or format, as long as you give appropriate credit to the original author(s) and the source, provide a link to the Creative Commons licence, and indicate if changes were made. The images or other third party material in this article are included in the article's Creative Commons licence, unless indicated otherwise in a credit line to the material. If material is not included in the article's Creative Commons licence and your intended use is not permitted by statutory regulation or exceeds the permitted use, you will need to obtain permission directly from the copyright holder. To view a copy of this licence, visit http://creativecommons.org/licenses/by/4.0/.

\section{References}

1. Bray F, Ferlay J, Soerjomataram I, Siegel RL, Torre LA, Jemal A (2018) Global cancer statistics 2018: GLOBOCAN estimates of incidence and mortality worldwide for 36 cancers in 185 countries. CA Cancer J Clin 68(6):394-424. https://doi.org/10.3322/caac. 21492

2. Postow MA, Sidlow R, Hellmann MD (2018) Immune-related adverse events associated with immune checkpoint blockade. N Engl J Med 378(2):158-168. https://doi.org/10.1056/NEJMra1703481

3. Esfahani K, Roudaia L, Buhlaiga N, Del Rincon SV, Papneja N, Miller WH Jr (2020) A review of cancer immunotherapy: from the past, to the present, to the future. Curr Oncol 27(Suppl 2):S87-s97. https://doi.org/10.3747/co.27.5223

4. Brahmer JR, Tykodi SS, Chow LQ, Hwu WJ, Topalian SL, Hwu P et al (2012) Safety and activity of anti-PD-L1 antibody in patients with advanced cancer. N Engl J Med 366(26):2455-2465. https:// doi.org/10.1056/NEJMoa1200694

5. Cortazar FB, Marrone KA, Troxell ML, Ralto KM, Hoenig MP, Brahmer JR, Le DT, Lipson EJ, Glezerman IG, Wolchok J, Cornell LD, Feldman P, Stokes MB, Zapata SA, Hodi FS, Ott PA, Yamashita M, LeafDE (2016) Clinicopathological features of acute kidney injury associated with immune checkpoint inhibitors. Kidney Int 90(3):638-647. https://doi.org/10.1016/j.kint.2016.04. 008

6. Jamal S, Hudson M, Fifi-Mah A, Ye C (2020) Immune-related adverse events associated with Cancer immunotherapy: a review for the practicing rheumatologist. J Rheumatol 47(2):166-175. https://doi.org/10.3899/jrheum.190084

7. Wanchoo R, Karam S, Uppal NN, Barta VS, Deray G, Devoe C, Launay-Vacher V, Jhaveri KD, Cancer, Kidney International Network Workgroup on Immune Checkpoint I (2017) Adverse renal effects of immune checkpoint inhibitors: a narrative review. Am J Nephrol 45(2):160-169. https://doi.org/10.1159/000455014

8. Iacovelli R, Ciccarese C, Fantinel E, Bimbatti D, Romano M, Porcaro AB, Siracusano S, Mazzarotto R, Artibani W, Tortora G (2017) Renal toxicity in patients treated with anti-Pd-1 targeted agents for solid tumors. J Onco-Nephrol 1(2):132-142. https:// doi.org/10.5301/jo-n.5000019

9. Cumpston M, Li T, Page MJ, Chandler J, Welch VA, Higgins JP, Thomas J (2019) Updated guidance for trusted systematic reviews: a new edition of the Cochrane handbook for systematic reviews of interventions. Cochrane Database Syst Rev 10:ED000142. https:// doi.org/10.1002/14651858.ED000142 
10. Moher D, Liberati A, Tetzlaff J, Altman DG, Group P (2010) Preferred reporting items for systematic reviews and meta-analyses: the PRISMA statement. Int J Surg 8(5):336-341. https://doi.org/10. 1016/j.ijsu.2010.02.007

11. Huang X, Lin J, Demner-Fushman D (2006) Evaluation of PICO as a knowledge representation for clinical questions. AMIA Annu Symp Proc 2006:359-363

12. Higgins JP, Altman DG, Gøtzsche PC, Jüni P, Moher D, Oxman AD, Savovic J, Schulz KF, Weeks L, Sterne JA (2011) The Cochrane Collaboration's tool for assessing risk of bias in randomised trials. BMJ 343:d5928. https://doi.org/10.1136/bmj. d5928

13. Higgins JPT (2003) Measuring inconsistency in meta-analyses. BMJ 327(7414):557-560. https://doi.org/10.1136/bmj.327.7414. 557

14. DerSimonian R, Laird N (2015) Meta-analysis in clinical trials revisited. Contemp Clin Trials 45(Pt A):139-145. https://doi.org/ 10.1016/j.cct.2015.09.002

15. Barlesi F, Vansteenkiste J, Spigel D, Ishii H, Garassino M, de Marinis F, Özgüroğlu M, Szczesna A, Polychronis A, Uslu R, Krzakowski M, Lee J-S, Calabrò L, Arén Frontera O, Ellers-Lenz B, Bajars M, Ruisi M, Park K (2018) Avelumab versus docetaxel in patients with platinum-treated advanced non-small-cell lung cancer (JAVELIN lung 200): an open-label, randomised, phase 3 study. Lancet Oncol 19(11):1468-1479. https://doi.org/10.1016/s14702045(18)30673-9

16. Bellmunt J, de Wit R, Vaughn DJ, Fradet Y, Lee JL, Fong L, Vogelzang NJ, Climent MA, Petrylak DP, Choueiri TK, Necchi A, Gerritsen W, Gurney H, Quinn DI, Culine S, Sternberg CN, Mai Y, Poehlein $\mathrm{CH}$, Perini RF, Bajorin DF, Investigators $\mathrm{K}$ (2017) Pembrolizumab as second-line therapy for advanced Urothelial carcinoma. N Engl J Med 376(11):1015-1026. https:// doi.org/10.1056/NEJMoa1613683

17. Borghaei H, Paz-Ares L, Horn L, Spigel DR, Steins M, Ready NE, Chow LQ, Vokes EE, Felip E, Holgado E, Barlesi F, Kohlhäufl M, Arrieta O, Burgio MA, Fayette J, Lena H, Poddubskaya E, Gerber DE, Gettinger SN, Rudin CM, Rizvi N, Crinò L, Blumenschein GR Jr, Antonia SJ, Dorange C, Harbison CT, Graf Finckenstein F, Brahmer JR (2015) Nivolumab versus Docetaxel in advanced nonsquamous non-small-cell lung Cancer. N Engl J Med 373(17): 1627-1639. https://doi.org/10.1056/NEJMoa1507643

18. Brahmer J, Reckamp KL, Baas P, Crino L, Eberhardt WE, Poddubskaya E et al (2015) Nivolumab versus Docetaxel in advanced squamous-cell non-small-cell lung Cancer. N Engl J Med 373(2):123-135. https://doi.org/10.1056/NEJMoa1504627

19. Carbone DP, Reck M, Paz-Ares L, Creelan B, Horn L, Steins M, Felip E, van den Heuvel M, Ciuleanu TE, Badin F, Ready N, Hiltermann TJN, Nair S, Juergens R, Peters S, Minenza E, Wrangle JM, Rodriguez-Abreu D, Borghaei H, Blumenschein GR Jr, Villaruz LC, Havel L, Krejci J, Corral Jaime J, Chang H, Geese WJ, Bhagavatheeswaran P, Chen AC, Socinski MA, CheckMate 026 Investigators (2017) First-line Nivolumab in stage IV or recurrent non-small-cell lung Cancer. N Engl J Med 376(25):24152426. https://doi.org/10.1056/NEJMoa1613493

20. Cohen EEW, Soulières D, Le Tourneau C, Dinis J, Licitra L, Ahn M-J et al (2019) Pembrolizumab versus methotrexate, docetaxel, or cetuximab for recurrent or metastatic head-and-neck squamous cell carcinoma (KEYNOTE-040): a randomised, open-label, phase 3 study. Lancet 393(10167):156-167. https://doi.org/10.1016/ s0140-6736(18)31999-8

21. Ferris RL, Blumenschein G Jr, Fayette J, Guigay J, Colevas AD, Licitra L, Harrington K, Kasper S, Vokes EE, Even C, Worden F, Saba NF, Iglesias Docampo LC, Haddad R, Rordorf T, Kiyota N, Tahara M, Monga M, Lynch M, Geese WJ, Kopit J, Shaw JW, Gillison ML (2016) Nivolumab for recurrent squamous-cell carcinoma of the head and neck. N Engl J Med 375(19):18561867. https://doi.org/10.1056/NEJMoa1602252

22. Herbst RS, Baas P, Kim D-W, Felip E, Pérez-Gracia JL, Han J-Y, Molina J, Kim J-H, Arvis CD, Ahn M-J, Majem M, Fidler MJ, de Castro G, Garrido M, Lubiniecki GM, Shentu Y, Im E, DolledFilhart M, Garon EB (2016) Pembrolizumab versus docetaxel for previously treated, PD-L1-positive, advanced non-small-cell lung cancer (KEYNOTE-010): a randomised controlled trial. Lancet 387(10027):1540-1550. https://doi.org/10.1016/s0140-6736(15) 01281-7

23. Mok TSK, Wu Y-L, Kudaba I, Kowalski DM, Cho BC, Turna HZ, Castro G Jr, Srimuninnimit V, Laktionov KK, Bondarenko I, Kubota K, Lubiniecki GM, Zhang J, Kush D, Lopes G, Adamchuk G, Ahn MJ, Alexandru A, Altundag O, Alyasova A, Andrusenko O, Aoe K, Araujo A, Aren O, Arrieta Rodriguez O, Ativitavas T, Avendano O, Barata F, Barrios CH, Beato C, Bergstrom P, Betticher D, Bolotina L, Bondarenko I, Botha M, Buddu S, Caglevic C, Cardona A, Castro G Jr, Castro H, Cay Senler F, Cerny CAS, Cesas A, Chan GC, Chang J, Chen G, Chen X, Cheng S, Cheng Y, Cherciu N, Chiu CH, Cho BC, Cicenas S, Ciurescu D, Cohen G, Costa MA, Danchaivijitr P, de Angelis F, de Azevedo SJ, Dediu M, Deliverski T, de Marchi PRM, de The Bustamante Valles F, Ding Z, Doganov B, Dreosti L, Duarte R, Edusma-Dy R, Emelyanov S, Erman M, Fan Y, Fein L, Feng J, Fenton D, Fernandes G, Ferreira C, Franke FA, Freitas H, Fujisaka Y, Galindo H, Galvez C, Ganea D, Gil N, Girotto G, Goker E, Goksel T, Gomez Aubin G, Gomez Wolff L, Griph H, Gumus M, Hall J, Hart G, Havel L, He J, He Y, Hernandez Hernandez C, Hespanhol V, Hirashima T, Ho CMJ, Horiike A, Hosomi Y, Hotta K, Hou M, How SH, Hsia TC, Hu Y, Ichiki M, Imamura F, Ivashchuk O, Iwamoto Y, Jaal J, Jassem J, Jordaan C, Juergens RA, Kaen D, Kalinka-Warzocha E, Karaseva N, Karaszewska B, Kazarnowicz A, Kasahara K, Katakami N, Kato T, Kawaguchi T, Kim JH, Kishi K, Kolek V, Koleva M, Kolman P, Koubkova L, Kowalyszyn R, Kowalski D, Koynov K, Ksienski D, Kubota K, Kudaba I, Kurata T, Kuusk G, Kuzina L, Laczo I, Ladrera GEI, Laktionov K, Landers G, Lazarev S, Lerzo G, Lesniewski Kmak K, Li W, Liam CK, Lifirenko I, Lipatov O, Liu X, Liu Z, Lo SH, Lopes V, Lopez K, Lu S, Martinengo G, Mas L, Matrosova M, Micheva R, Milanova Z, Miron L, Mok T, Molina M, Murakami S, Nakahara Y, Nguyen TQ, Nishimura T, Ochsenbein A, Ohira T, Ohman R, Ong CK, Ostoros G, Ouyang X, Ovchinnikova E, Ozyilkan O, Petruzelka L, Pham XD, Picon P, Piko B, Poltoratsky A, Ponomarova O, Popelkova P, Purkalne G, Qin S, Ramlau R, Rappaport B, Rey F, Richardet E, Roubec J, Ruff P, Rusyn A, Saka H, Salas J, Sandoval M, Santos L, Sawa T, Seetalarom K, Seker M, Seki N, Seolwane F, Shepherd L, Shevnya S, Shimada AK, Shparyk Y, Sinielnikov I, Sirbu D, Smaletz O, Soares JPH, Sookprasert A, Speranza G, Srimuninnimit V, Sriuranpong V, Stara Z, Su WC, Sugawara S, Szpak W, Takahashi K, Takigawa N, Tanaka H, Tan Chun Bing J, Tang Q, Taranov P, Tejada H, Tho LM, Torii Y, Trukhyn D, Turdean M, Turna H, Ursol G, Vanasek J, Varela M, Vallejo M, Vera L, Victorino AP, Vlasek T, Vynnychenko I, Wang B, Wang J, Wang K, Wu Y, Yamada K, Yang CH, Yokoyama T, Yokoyama T, Yoshioka H, Yumuk F, Zambrano A, Zarba JJ, Zarubenkov O, Zemaitis M, Zhang L, Zhang L, Zhang X, Zhao J, Zhou C, Zhou J, Zhou Q, Zippelius A (2019) Pembrolizumab versus chemotherapy for previously untreated, PD-L1-expressing, locally advanced or metastatic non-small-cell lung cancer (KEYNOTE-042): a randomised, open-label, controlled, phase 3 trial. Lancet 393(10183):1819-1830. https://doi.org/10.1016/s0140-6736(18) 32409-7

24. Reck M, Rodriguez-Abreu D, Robinson AG, Hui R, Csoszi T, Fulop A, Gottfried M, Peled N, Tafreshi A, Cuffe S, O'Brien M, Rao S, Hotta K, Leiby MA, Lubiniecki GM, Shentu Y, Rangwala 
R, Brahmer JR, Investigators K (2016) Pembrolizumab versus chemotherapy for PD-L1-positive non-small-cell lung Cancer. N Engl J Med 375(19):1823-1833. https://doi.org/10.1056/ NEJMoa1606774

25. Ribas A, Puzanov I, Dummer R, Schadendorf D, Hamid O, Robert C, Hodi FS, Schachter J, Pavlick AC, Lewis KD, Cranmer LD, Blank CU, O'Day SJ, Ascierto PA, Salama AKS, Margolin KA, Loquai C, Eigentler TK, Gangadhar TC, Carlino MS, Agarwala SS, Moschos SJ, Sosman JA, Goldinger SM, Shapira-Frommer R, Gonzalez R, Kirkwood JM, Wolchok JD, Eggermont A, Li XN, Zhou W, Zernhelt AM, Lis J, Ebbinghaus S, Kang SP, Daud A (2015) Pembrolizumab versus investigator-choice chemotherapy for ipilimumab-refractory melanoma (KEYNOTE-002): a randomised, controlled, phase 2 trial. Lancet Oncol 16(8):908918. https://doi.org/10.1016/s1470-2045(15)00083-2

26. Robert C, Long GV, Brady B, Dutriaux C, Maio M, Mortier L, Hassel JC, Rutkowski P, McNeil C, Kalinka-Warzocha E, Savage KJ, Hernberg MM, Lebbé C, Charles J, Mihalcioiu C, ChiarionSileni V, Mauch C, Cognetti F, Arance A, Schmidt H, Schadendorf D, Gogas H, Lundgren-Eriksson L, Horak C, Sharkey B, Waxman IM, Atkinson V, Ascierto PA (2015) Nivolumab in previously untreated melanoma without BRAF mutation. N Engl J Med 372(4): 320-330. https://doi.org/10.1056/NEJMoa1412082

27. Robert C, Schachter J, Long GV, Arance A, Grob JJ, Mortier L, Daud A, Carlino MS, McNeil C, Lotem M, Larkin J, Lorigan P, Neyns B, Blank CU, Hamid O, Mateus C, Shapira-Frommer R, Kosh M, Zhou H, Ibrahim N, Ebbinghaus S, Ribas A, investigators K (2015) Pembrolizumab versus Ipilimumab in Advanced Melanoma. N Engl J Med 372(26):2521-2532. https://doi.org/10. 1056/NEJMoa1503093

28. Tomita Y, Fukasawa S, Shinohara N, Kitamura H, Oya M, Eto M, Tanabe K, Saito M, Kimura G, Yonese J, Yao M, Uemura H (2019) Nivolumab versus everolimus in advanced renal cell carcinoma: Japanese subgroup 3-year follow-up analysis from the phase III CheckMate 025 study. Jpn J Clin Oncol 49(6):506-514. https:// doi.org/10.1093/jjco/hyz026

29. Weber JS, D'Angelo SP, Minor D, Hodi FS, Gutzmer R, Neyns B, Hoeller C, Khushalani NI, Miller WH Jr, Lao CD, Linette GP, Thomas L, Lorigan P, Grossmann KF, Hassel JC, Maio M, Sznol M, Ascierto PA, Mohr P, Chmielowski B, Bryce A, Svane IM, Grob JJ, Krackhardt AM, Horak C, Lambert A, Yang AS, Larkin J (2015) Nivolumab versus chemotherapy in patients with advanced melanoma who progressed after anti-CTLA-4 treatment (CheckMate 037): a randomised, controlled, open-label, phase 3 trial. Lancet Oncol 16(4):375-384. https://doi.org/10.1016/s14702045(15)70076-8

30. Eggermont AMM, Blank CU, Mandala M, Long GV, Atkinson V, Dalle S, Haydon A, Lichinitser M, Khattak A, Carlino MS, Sandhu S, Larkin J, Puig S, Ascierto PA, Rutkowski P, Schadendorf D, Koornstra R, Hernandez-Aya L, Maio M, van den Eertwegh AJM, Grob JJ, Gutzmer R, Jamal R, Lorigan P, Ibrahim N, Marreaud S, van Akkooi ACJ, Suciu S, Robert C (2018) Adjuvant Pembrolizumab versus placebo in resected stage III melanoma. N Engl J Med 378(19):1789-1801. https://doi.org/10.1056/ NEJMoa1802357

31. Hida T, Kaji R, Satouchi M, Ikeda N, Horiike A, Nokihara H, Seto T, Kawakami T, Nakagawa S, Kubo T (2018) Atezolizumab in Japanese patients with previously treated advanced non-small-cell lung Cancer: a subgroup analysis of the phase 3 OAK study. Clin Lung Cancer 19(4):e405-e415. https://doi.org/10.1016/j.cllc.2018. 01.004

32. Schachter J, Ribas A, Long GV, Arance A, Grob J-J, Mortier L, Daud A, Carlino MS, McNeil C, Lotem M, Larkin J, Lorigan P, Neyns B, Blank C, Petrella TM, Hamid O, Zhou H, Ebbinghaus S, Ibrahim N, Robert C (2017) Pembrolizumab versus ipilimumab for advanced melanoma: final overall survival results of a multicentre, randomised, open-label phase 3 study (KEYNOTE-006). Lancet 390(10105):1853-1862. https://doi.org/10.1016/s0140-6736(17) 31601-x

33. Gandhi L, Rodriguez-Abreu D, Gadgeel S, Esteban E, Felip E, De Angelis F et al (2018) Pembrolizumab plus chemotherapy in metastatic non-small-cell lung Cancer. N Engl J Med 378(22):20782092. https://doi.org/10.1056/NEJMoa1801005

34. Horn L, Mansfield AS, Szczesna A, Havel L, Krzakowski M, Hochmair MJ, Huemer F, Losonczy G, Johnson ML, Nishio M, Reck M, Mok T, Lam S, Shames DS, Liu J, Ding B, Lopez-Chavez A, Kabbinavar F, Lin W, Sandler A, Liu SV, Group IMS (2018) First-line Atezolizumab plus chemotherapy in extensive-stage small-cell lung Cancer. N Engl J Med 379(23):2220-2229. https://doi.org/10.1056/NEJMoa1809064

35. Langer CJ, Gadgeel SM, Borghaei H, Papadimitrakopoulou VA, Patnaik A, Powell SF, Gentzler RD, Martins RG, Stevenson JP, Jalal SI, Panwalkar A, Yang JC-H, Gubens M, Sequist LV, Awad MM, Fiore J, Ge Y, Raftopoulos H, Gandhi L (2016) Carboplatin and pemetrexed with or without pembrolizumab for advanced, non-squamous non-small-cell lung cancer: a randomised, phase 2 cohort of the open-label KEYNOTE-021 study. Lancet Oncol 17(11):1497-1508. https://doi.org/10.1016/s1470-2045(16)30498-3

36. Paz-Ares L, Luft A, Vicente D, Tafreshi A, Gumus M, Mazieres J, Hermes B, Cay Senler F, Csoszi T, Fulop A, Rodriguez-Cid J, Wilson J, Sugawara S, Kato T, Lee KH, Cheng Y, Novello S, Halmos B, Li X, Lubiniecki GM, Piperdi B, Kowalski DM, Investigators K (2018) Pembrolizumab plus chemotherapy for squamous non-small-cell lung Cancer. N Engl J Med 379(21): 2040-2051. https://doi.org/10.1056/NEJMoa1810865

37. Schmid P, Adams S, Rugo HS, Schneeweiss A, Barrios CH, Iwata H, Dieras V, Hegg R, Im SA, Shaw Wright G, Henschel V, Molinero L, Chui SY, Funke R, Husain A, Winer EP, Loi S, Emens LA, Investigators IMT (2018) Atezolizumab and nabpaclitaxel in advanced triple-negative breast Cancer. N Engl $\mathrm{J}$ Med 379(22):2108-2121. https://doi.org/10.1056/ NEJMoa1809615

38. Socinski MA, Jotte RM, Cappuzzo F, Orlandi F, Stroyakovskiy D, Nogami N, Rodriguez-Abreu D, Moro-Sibilot D, Thomas CA, Barlesi F, Finley G, Kelsch C, Lee A, Coleman S, Deng Y, Shen Y, Kowanetz M, Lopez-Chavez A, Sandler A, Reck M, Group IMS (2018) Atezolizumab for first-line treatment of metastatic nonsquamous NSCLC. N Engl J Med 378(24):2288-2301. https://doi.org/10.1056/NEJMoa1716948

39. West H, McCleod M, Hussein M, Morabito A, Rittmeyer A, Conter HJ, Kopp H-G, Daniel D, McCune S, Mekhail T, Zer A, Reinmuth N, Sadiq A, Sandler A, Lin W, Ochi Lohmann T, Archer V, Wang L, Kowanetz M, Cappuzzo F (2019) Atezolizumab in combination with carboplatin plus nabpaclitaxel chemotherapy compared with chemotherapy alone as first-line treatment for metastatic non-squamous non-smallcell lung cancer (IMpower130): a multicentre, randomised, open-label, phase 3 trial. Lancet Oncol 20(7):924-937. https:// doi.org/10.1016/s1470-2045(19)30167-6

40. Hodi FS, Chesney J, Pavlick AC, Robert C, Grossmann KF, McDermott DF, Linette GP, Meyer N, Giguere JK, Agarwala SS, Shaheen M, Ernstoff MS, Minor DR, Salama AK, Taylor MH, Ott PA, Horak C, Gagnier P, Jiang J, Wolchok JD, Postow MA (2016) Combined nivolumab and ipilimumab versus ipilimumab alone in patients with advanced melanoma: 2-year overall survival outcomes in a multicentre, randomised, controlled, phase 2 trial. Lancet Oncol 17(11):1558-1568. https://doi.org/10.1016/s14702045(16)30366-7

41. Wolchok JD, Chiarion-Sileni V, Gonzalez R, Rutkowski P, Grob JJ, Cowey CL, Lao CD, Wagstaff J, Schadendorf D, Ferrucci PF, Smylie M, Dummer R, Hill A, Hogg D, Haanen 
J, Carlino MS, Bechter O, Maio M, Marquez-Rodas I, Guidoboni M, McArthur G, Lebbé C, Ascierto PA, Long GV, Cebon J, Sosman J, Postow MA, Callahan MK, Walker D, Rollin L, Bhore R, Hodi FS, Larkin J (2017) Overall survival with combined Nivolumab and Ipilimumab in advanced melanoma. N Engl J Med 377(14):1345-1356. https://doi.org/10. 1056/NEJMoa1709684

42. Zheng K, Qiu W, Wang H, Si X, Zhang X, Zhang L, Li X (2020) Clinical recommendations on diagnosis and treatment of immune checkpoint inhibitor-induced renal immune-related adverse events. Thorac Cancer 11(6):1746-1751. https://doi.org/10.1111/17597714.13405

43. Seethapathy H, Zhao S, Chute DF, Zubiri L, Oppong Y, Strohbehn I, Cortazar FB, Leaf DE, Mooradian MJ, Villani AC, Sullivan RJ, Reynolds K, Sise ME (2019) The incidence, causes, and risk factors of acute kidney injury in patients receiving immune checkpoint inhibitors. Clin J Am Soc Nephrol 14(12):1692-1700. https://doi. org/10.2215/CJN.00990119

44. $\mathrm{Hu} \mathrm{R}$, Chen M, Xu Y, Wang M, Zheng K, Li X (2020) Renal immune-related adverse events of immune checkpoint inhibitor. Asia Pac J Clin Oncol 16:305-311. https://doi.org/10.1111/ajco. 13387
45. Mamlouk O, Selamet U, Machado S, Abdelrahim M, Glass WF, Tchakarov A, Gaber L, Lahoti A, Workeneh B, Chen S, Lin J, Abdel-Wahab N, Tayar J, Lu H, Suarez-Almazor M, Tannir N, Yee C, Diab A, Abudayyeh A (2019) Nephrotoxicity of immune checkpoint inhibitors beyond tubulointerstitial nephritis: singlecenter experience. J Immunother Cancer 7(1):2. https://doi.org/10. 1186/s40425-018-0478-8

46. Brahmer JR, Lacchetti C, Schneider BJ, Atkins MB, Brassil KJ, Caterino JM, Chau I, Ernstoff MS, Gardner JM, Ginex P, Hallmeyer S, Holter Chakrabarty J, Leighl NB, Mammen JS, McDermott DF, Naing A, Nastoupil LJ, Phillips T, Porter LD, Puzanov I, Reichner CA, Santomasso BD, Seigel C, Spira A, Suarez-Almazor ME, Wang Y, Weber JS, Wolchok JD, Thompson JA, in collaboration with the National Comprehensive Cancer Network (2018) Management of Immune-Related Adverse Events in patients treated with immune checkpoint inhibitor therapy: American Society of Clinical Oncology clinical practice guideline. J Clin Oncol 36(17):1714-1768. https://doi.org/10.1200/jco. 2017.77.6385

Publisher's note Springer Nature remains neutral with regard to jurisdictional claims in published maps and institutional affiliations. 